\title{
Three Approaches to Psychoanalytic Psychotherapy in Aotearoa New Zealand
}

\author{
Judi Blumenfeld Hoadley, Sarah Calvert, \\ Gustavo Restivo and Mark Thorpe \\ PSYCHOANALYTIC PSYCHOTHERAPIST AND CLINICAL SUPERVISOR \\ CLINICAL PSYCHOLOGIST AND PSYCHOTHERAPIST, \\ Clinical psychologist at Child, Youth and Family, Specialist Services and \\ PRIVATE PRACTICE, \\ Senior lecturer, AUCKLANd University of TeCHNOLOgy AND CLINICAL \\ psychologist at Psychotherapy at Apollo, All Auckland
}

\begin{abstract}
This paper discusses three styles of psychoanalytic psychotherapy commonly practiced in Aotearoa New Zealand. Judi Blumenfeld Hoadley writes on object relations, Gustavo Restivo on the Lacanian orientation, and Sarah Calvert on relational psychoanalysis and the relational movement.Each author discusses their specific orientation towards psychoanalytic psychotherapy in terms of the historical origins, seminal theorists, and philosophical views. They also articulate the key theoretical concepts, clinical techniques, and unique links to the therapeutic relationship. Finally, the authors point out the specific organisations, training, and conferences available in Aotearoa New Zealand.
\end{abstract}

\section{Waitara}

Ko tā tēnei tuhinga he matapakinga o ètahi momo kakenga mahi whakaora hinengaro mahia ai i Aotearoa Niu Tireni. Ko tā Hūria Purumanawheri Hoari, arā, Judi Blumenfeld Hoadley he titiro ki ngā pānga tupua, ko tā Karitawa Rehitio, arā, Gustavo Restivo, he titiro ki te aronga à-Rakaniana, ā, ko tā Hera Kariwhata, arā Sarah Calvert, he titiro ki te whaiaro tātarihanga me ōna pānga nekenekehanga. Ka huri ia kaituhi ki tōna ake tūranga whakapā atu ki te tūnga a te tātarihanga whakaora hinengaro mai i ōna pūnga ake, ngā whakapaenga whakahiranga me ngā tirohanga wānanga. Ka whakaarahia ake hoki e rātou ngā aroro ariā, ngā momo haumanu, me ngā here ki te piringa haumanu. I te mutunga, ka tohua ake e ngā kaituhi ngā rōpū

Key words: Object relations; relational psychoanalysis; Lacan; psychoanalytic psychotherapy

Blumenfeld Hoadley, J., Calvert, S., Restivo, G., \& Thorpe, M. (2016). Three approaches to psychoanalytic psychotherapy in Aotearoa New Zealand. Ata: Journal of Psychotherapy Aotearoa New Zealand, 20(2), 111-128. DOI:10.9791/ajpanz.2016.11 $\odot$ New Zealand Association of Psychotherapists Inc. 


\section{Introduction}

At the start of the 21st century, there were more than a thousand named psychotherapies (Feltham, 1997; Lebow, 2017). Many of these have been significantly altered and some have disappeared completely (Dumont, 2008). Anecdotally, in Aotearoa New Zealand, counsellors adopt a humanistic approach, psychotherapists are psychodynamic, and clinical psychologists follow a behavioural or cognitive behavioural path (Thorpe, 2015). This paper presents three commonly practiced psychoanalytic psychotherapy approaches in Aotearoa New Zealand. A senior practitioner, regarded as an expert in the particular therapeutic style, authors each section. Judi Blumenfeld Hoadley writes on object relations, Sarah Calvert focusses on relational psychoanalysis and the relational movement, and Gustavo Restivo writes on the Lacanian orientation. Each author begins with an introduction of the theory, which includes the historical origins, seminal theorists, and philosophical views. They then articulate the key theoretical concepts and techniques and link this to conceptions of the therapeutic relationship. Finally, the authors discuss specific organisations, conferences, and training available in Aotearoa New Zealand for each specific therapeutic orientation.

\section{Object Relations - Judi Blumenfeld Hoadley}

What does the term "object relations" mean? As a reference to a model of psychoanalytic psychotherapy, it can seem somewhat opaque and confusing, perhaps because it encompasses a number of interwoven and overlapping meanings that straddle the psychoanalytic field. Object relations may be understood as: 1) a way of thinking and working that privileges the patient's internal, largely unconscious world and particularly the influence of the patient's version of early attachment figures on personality development. This definition encompasses the bulk of psychoanalytic theory, from Freud to much of contemporary psychoanalysis; 2) A discreet theoretical grouping within an historical context initially charted by two distinctive psychoanalytic thinkers Melanie Klein and Ronald Fairbairn, with the ensuing divergent views of human development as they have come to be represented by various psychoanalytic schools; 3) Object relations as seen through an attachment theory lens in the sense of a developing shared concern with the importance of internal representations in the infant and (m)other and an acceptance of what Fonagy (2001) called the possibility of plurality in theory; 4) The specific use of the object relational view as applied to certain practice modalities such as couple and family therapy: an intimate other comes to represent a troublesome internal object, or aspect of an object relationship, for instance, so that one has a schema for a shared object relational system (Framo, 1976; Scharff \& Scharff, 1977, 2000; Skynner, 1976).

Despite these referential differences, object relations theory has three fundamental commonalities. Firstly, the move away from Freud's initial assumption of the drive as primarily tension reducing to a view of the human being, motivated by specific developmental and survival needs, as fundamentally (object) relation-seeking. Secondly, the early, pre-oedipal development of object relationships. Thirdly, the assumption of significant unconscious motivation and action in regard to the activity of the mind, that our (internal) object world, is only to varying degrees within our conscious recognition, and that, for better or worse, we may have little conscious understanding of the emotional impact of this world on our everyday life, our relationships, and our decision-making. It follows that a primary 
goal of psychoanalytic psychotherapy is to lessen the grip of this internal object world in order to potentialise emotional health and freedom.

\section{Theory}

Freud, in the development and revision of his theory, first provided the landscape for the concept of object relations. Thomas Ogden (2002) argued persuasively that Freud's (1917) paper, Mourning and Melancholia, certainly amongst the first modern expositions on depression, provided a watershed in this regard. Here, Freud shows the part played by the melancholic ego in forming an unconscious identificatory relationship to aspects of the lost person-as-object to avoid the pain of loss. Freud's famous phrase, "the shadow of the object lies upon the ego", suggests that the way the object has been internalised affects the outcome of mourning: a view of the object grounded in reality allows for the possibility of true mourning. The paper included Freud's first reference to a form of superego, further developed in his 1923 paper and demonstrably really itself a form of internal object.

In 1917, Freud, doing a spot of babysitting for his daughter Sophie, observed his little 18 month grandson Ernst playing with a spool which he would repetitively raise and lower from his cot with the words "fort" and "da". Freud interpreted this as the infant's developmentally appropriate internal working through of a separation anxiety through an omnipotent control of the absent object- $(\mathrm{m})$ other. The process of evoking again and again the memory of the object is integral to the acquisition of object constancy, itself seen as a central factor by both attachment and object relations theorists in the development of healthy object relationships. In the next years, Freud was to amend his theory to acknowledge the primacy of anxiety in relation to the defences and personality formation.

It was Melanie Klein who took the implications of Freud's theory, and, in her work with very young children, first delineated a theory of object relations. Klein had been influenced by Abraham, her analyst and Freud's close associate, who had noticed in his work with psychotic patients their anxiety around their "objects" - bodily functions were identified with loved or hated others in quite a concrete way. Klein observed a similar phenomenon in her anxious young patients; she theorised that the drives were from the very beginning of life, object related taking the form of unconscious phantasies (for the use of the "ph" in phantasy see Hinshelwood, 1988), the nature of which provide a blueprint for personality development. Introjective and projective processes involving primitive loving and hateful feelings are directed at the mother as primary internal object. The infant protects its relationship with mother from its phantasised projections in a process called "splitting"; when the loving mother/breast is present in the mind, the hate is split out of consciousness and vice versa. Susan Issacs (1948) noted that phantasies are experienced first as body sensations, later as plastic images, and eventually in words.

\section{Example}

Some years ago, before entering a familiar group situation I saw myself as automatically taking up my place seated on the floor. It was only after some time that I realised that I, like other group members, was actually occupying a chair. I then had the further realisation that the floor image was a consistent representation of myself in a group setting. The power of the experience led me to think that this constituted a phantasised object relationship 
between a helpless infant part of me and the omnipresent fearsome group (m)other. I speculated that my style in groups, and others' view of me, might be influenced by this phantasy. (This is not to deny the influence of the group process.) I then intuited that my way of defending my helpless self-in-phantasy was to remain very "grown-up" in an unconscious process of a projected omnipotent control over my internal world. I felt that the phantasy could to some extent account for the discrepancy I had observed between the way I viewed myself and others' apparent view of me. It became evident to me that my emotional recognition of this disjunction simultaneously lessened the grip of the phantasy.

The Kleinian influenced object relational mode of working through, stands in some contrast to a trauma model where the emphasis would be with the pain of the helpless infant. While this pain would be recognised and worked with, the object relations therapist would, on balance, be primarily concerned with the unhelpful functioning of the mind emanating from early experience.

Klein's schemas of the paranoid schizoid and depressive positions, perhaps her greatest contribution, encompassed two fundamental modes of object relating. They refer not only to developmental stages of early infancy, but to life-long, inner-directed, and fluid ways of responding which construct and define our ordinary relationships. Klein translated Freud's idea of a death instinct as the infant's projected persecutory anxiety taking the form of partobject destructive phantasies (paranoid schizoid position). As the infant's world in relation to herself matures, there develops a gradual recognition and appreciation of the (m)other with the range of her qualities, an understanding of one's emotional impact on the other and an ensuing capacity for reparative relationship (depressive position). The small child comes to accept the (m)other as a separate being with her own thoughts and life, just as there emerges a psychic recognition of the couple and versions of its own exclusion and inclusion (Blumenfeld Hoadley, 2016). [See the review of Hooke's workshop in this issue.]

At the same time that Klein was developing her theory, Ronald Fairbairn, a Scottish psychoanalyst, was developing a contrasting object relational theory. Fairbairn (1952, 1941, 1943, 1944, 1949) could not accept the Freud/Kleinian view of innate aggression. Rather, he saw all emotional disturbance as stemming from an infant's overly frustrating, unloving relationship with the mother, with the infant now forming an object relational world based on the omnipotent phantasy: I am the cause of this disaster and I need to make amends. Fairbairn's structural model of object relationships includes a central operational ego and two split off part-egos: the libidinal ego (loving) and the antilibidinal ego (internal saboteur) which interact with two part-objects: the tantalising and rejecting parts of the object (m)other. Fairbairn emphasised the serious consequences of the internal saboteur on the development of children faced with the trauma of emotional neglect and parental abuse. However, like Klein and other object relations theorists, he saw the task of the psychotherapist as primarily modifying these internal representations to facilitate acceptance of external (ordinary) reality.

Fairbairn's idea of schizoid splitting of the ego allowed Klein to make crucial extensions to her own ideas. She outlined these in her seminal paper, "Notes on some schizoid mechanisms" (Klein, 1946), which brought the term paranoid-schizoid into focus and for the first time introduced the theory of projective identification [see Thorpe's paper on projective identification in this issue] and with it the implication of a two-person psychology. It was Klein's protégé, Wilfred Bion, who brought this to fruition with his notion of 
containment, a concept which has provided the psychoanalytic field with an overarching motif and working model and which incidentally provides an important linking element between the object relations school and the post-modernists; notably, between the work of the contemporary Kleinians and the American Relationists. Both Fairbairn and Klein also influenced the work of the American object relations analysts Kernberg, and Masterson and Rinsley who translated these concepts into models for working with the borderline and narcissistic disorders. There has been confluence also between Fairbairn's notions of ego states and the humanistic psychotherapies; notably transactional analysis which might itself be seen as an object relations theory.

Object relations theory and practice was taken into a further realm by the psychoanalyst Donald Winnicott, like Fairbairn a founding member of what was to become known as the British Middle School (see Hayman, 1994, on the Controversial Discussions). Winnicott was the first theorist to look at the child's internal world in relation to the enlivenment or depletion of the Self. His interest was the creative self in relation to both the real and the internal world and how this is mediated through our object world. Winnicott's (1953) theory of the transitional object, the ordinary "meaningless" toy or piece of cloth chosen and given special (internal) meaning by the baby, which is neither "me nor not-me" but comes to hold the meaning and psychic energy of the mother/infant relationship until it can be naturally relinquished, provides a central construct, not only for healthy development but for the process of psychotherapy itself. Winnicott privileged the early mother/infant "holding environment" and saw maternal "impingements" as setting the scene for breakdown of the self and for paucity of self-motivation.

Winnicott is often seen as an attachment theorist but belongs more properly to the psychoanalytic object relations tradition. However, his writings on self-representations and his observational work with children provide linkage between the object relations field, developmental psychology, and attachment theory.

However important the mother/infant dyad to object relations, conceptually central to the theory is the idea of oedipal space. The psychotherapist is seen as representing the mind of the parental couple in relation to the growing child and the role of both parents in the achievement of psychological freedom is openly avowed. As Britton (2004) stated:

If the link between the parent is perceived in love, and hate can be tolerated in the child's mind, it provides the child with an object relationship of a third kind in which he or she is a witness and not a participant. A third position then comes into existence from which object relationships can be observed. (p. 47)

It is this achievement of observational space, what Winnicott (1969) in "The Use of an Object" named as the movement from object relating (by which he meant unconsciously the primitive relating to the other as an extension of the self) to object usage (recognition of the other with the capacity to think and act separately), which signifies emotional health.

From the 1950 s onwards, the object relational field in both the United Kingdom and the United States broadened to include a systems view: in the United Kingdom specifically in the field of couple and group therapy and in the United States through the medium of family therapy. With the understanding of projective processes, and particularly projective 
identification, it is understood that an individual could act psychologically on behalf of a couple or a group. Alternatively, a "sick" (family) system could find homeostasis by "choosing" a member, the most likely recipient of a group or family projection, as identified patient.

The understandings about oedipal space and the projective and introjective processes, as they manifest in a system, have enhanced all modalities (group/family, couple and individual) of object relations work.

\section{Practice}

Psychotherapists identifying with object relations theory and practice have tended to move away from actively interpreting the patient's inner world and the defences, to a clinical use of the transference/countertransference relationship (by this I mean also the use of the setting, the frame, and the total situation of the therapy) as an interpretative and integrative tool.

This involves the patient's view of the psychotherapist as $\mathrm{s} / \mathrm{h}$ comes to represent for the patient his/her internal object world as opposed to the psychotherapist as a real person, and the psychotherapist's use of his/her own process together with clinical understanding to inform the work. At the same time, most contemporary object relations therapists recognise that the person of the therapist provides both a powerful holding and containing presence. However, this remains a background rather than a foreground presence.

Contemporary object relations therapists work in the here-and-now of the session, drawing links, together with the patient, between the emotional data of the transference/ countertransference and the connective relevance of the issues presented, rather than necessarily concentrating on direct linkage of past and present. Particularly relevant are Heinrich Racker's $(1953,1957)$ concept of concordant and complementary countertransferences and Joseph Sandler's (1976) idea of role responsiveness. The idea that a therapeutic enactment, in previous times often seen as an error on the part of the therapist, actually serves as a powerful informational tool would be central to the practice of object relations practice for the psychoanalytic psychotherapist.

\section{Object Relations Practice in Aotearoa New Zealand}

The object relations tradition in Aotearoa New Zealand had its origins in both Dunedin (The Ashburn Clinic, formerly Ashburn Hall) and in Auckland (the former Auckland Family Counselling and Psychotherapy Centre). Currently, the Auckland based New Zealand Institute of Psychoanalytic Psychotherapy (NZIPP) offers the only fully recognised and certified broadbased post registration psychoanalytic psychotherapy training available in the country. The membership of the Institute leads to membership of the Psychoanalytic Psychotherapy Association of Australasia (PPAA) (see website for training and events http://theppaa.com/ about-us/).

NZIPP and the PPAA have professional connections also to the Australian Psychoanalytic Association, a branch of the International Psychoanalytic Association.

For membership or training enquiries contact: Miranda Thorpe secretary.nzipp@gmail. com

For further information, refer to the NZIPP website http://www.psychotherapy.co.nz/ 


\section{Relational Psychoanalysis and the Relational Movement - Sarah Calvert}

The relational movement in psychoanalysis was begun by Stephen Mitchell and Jay Greenberg and colleagues (mostly at New York University) in 1983. The term represented an alternate proposition to the prevailing drive-based view of psychic structure. Mitchell and others sought to challenge the orthodoxy of classical psychoanalysis, especially as it was constituted in the United States.

The relational movement developed at a time when orthodox drive theory was being challenged by a number of new traditions including the self-psychology model of Kohut. American analysts and therapists were also beginning to be interested in writers like Winnicott, Bion, Klein, and Ferenzi.

Mitchell and other early relational thinkers did not seek to put aside the critical insights developed by Freud and those who followed him. Relational psychoanalysis is embedded in that tradition. The core aspects of the analytic tradition - the role of unconscious process in the mind, the importance of the relationship between the mind and the body, the careful listening to the client, the use of dialectics such as that between fantasy and reality, the role of the past and the present, and the importance of transference and resistance - all remain central in relational work.

However, relational thinking was also situated in the ferment of ideas across a wide range of social-political and philosophical areas, which began in the mid 1960 s and into the 1970 . Some of the most significant writers, such as Jessica Benjamin, came to psychoanalysis through intellectual and political engagement with radical change thinking and movements. Relational Psychoanalysis has always presented a strong feminist voice and more recently has embraced thinking about gender, sexuality, marginalisation, and culture. It has sought to actively explore the relationship that exists in therapy, making the analyst or therapist a participant in the process.

Mitchell, before his untimely death in 2001, wrote about and sought a more open and inclusive form of analysis (psychotherapy) which might consider the mutuality of the therapeutic dyad. Mitchell also had a political view of psychoanalysis, seeking to have training open to all and envisaging the involvement of other intellectual disciplines, more akin to the way psychoanalysis had developed in Europe.

Mitchell's vision led to the founding of the International Association for Relational Psychoanalysis and Psychotherapy (IARPP) in 2001. As discussed by Jessica Benjamin in the first IARPP newsletter, a fundamental aim of IARPP was to create a more inclusive and democratic movement within the psychoanalytic field. That meant the IARPP was an open organisation where therapists, including those without the formally recognised qualifications required in other similar organisations, were as welcome as those with a traditional academically and institute-driven training and experience of personal analysis.

The growth of relational psychoanalysis was aided by the development of what was called the "relational track" at NYU in the Post-Doctoral Program in Psychotherapy and by the development of Division 38 in the American Psychoanalytic Association (APA). These provided an academic basis for the thinking behind relational work and the publication Psychoanalytic Dialogues provided a forum for both theoretical and clinical work.

The inaugural IARPP conference was held in January 2002. IARPP now has members 
throughout the world, holds a yearly conference (the next being in Sydney Australia in May 2017) and offers learning opportunities and collegial interactions across a number of internet-based platforms (an ENews, regular webinars, colloquium, and small group learning opportunities). Aotearoa New Zealand has its own chapter and relational therapists from New Zealand have featured as presenters, discussants, moderators, and panellists at conferences and online activities. In Aotearoa New Zealand, a number of very successful small conferences and colloquium have been held and IARPP has co-hosted a conference with other analytic institutions from the USA and Canada.

\section{Relational Psychoanalysis - The ideas}

Emmanuel Ghent (2002), in his introduction to the first IARPP Conference, said there is no such thing as relational theory but there is "relational thinking" and a "relational sensibility". The ideas that have informed the relational movement recognise that therapists and analysts are participant observers in the process of therapy and that therapy is a relationship. The ideas developed by Harry Stack Sullivan and his assertion that the mind always emerges and develops contextually in the interpersonal field was critical in the development of the ideas within the relational movement.

Relational thinking focused on the way in which the mind is constructed through the organisation of experience, especially inter-human experience. It emphasises the role of real and imagined relationships with others in mental disorder and psychotherapy. It was these processes which could become accessible in therapy where poorly organised experience (psychopathology) or experience which could not be integrated (was primarily dissociated) could be conceptualised and worked with in a relational context.

The introduction to the NYU relational track says this about relational psychoanalysis "Relational psychoanalysis focuses attention on processes of mutual influence in development and treatment. We assume that relationships, including the analytic one, are shaped by both individuals in a process that is neither one sided nor linear" (Ghent, 2002, p. 9).

The relational movement has provided fertile ground for many significant thinkers and re-thinkers of the analytic tradition. Among them are Emanuel Ghent, Lew Aron, Jessica Benjamin, Jody Davis, Muriel Dimen, Philip Bromberg, Phil Ringstrom, Mal Slavin, Michael Eigen, Irwin Hoffman, Donnel Stern, Adrienne Harris, Beatrice Beebe, and newer writers such as Jill Gentile.

Jessica Benjamin (1988) noted that relational psychoanalysis "may best be characterised as an inquiry into questions of common concern that have come to the fore as a result of the adoption of the two person model”. Benjamin's (1988) seminal work, The Bonds of Love and her development of the concept of "the third" within therapeutic work brought the relational movement to a wider audience.

Relational therapists regard the real relationship between therapist and client as critical and stress the value of a holding environment which allows the inner world of both the client and the therapist to come into being in the work. It also stresses the need for the relationship to be authentic, real, and available. Writers such as Nancy McWilliams and Karen Maroda have articulated the strengths and the difficulties of working in such a way, and the relational literature contains excellent discussions about issues such as the meanings of enactments and their management. Core in relational work is the use of the 
therapeutic relationship itself as a vehicle for change, as well as the work to develop selfcapacity and insight in a client. Self-capacity and insight are considered to develop within the mutual construction of meaning in the analytic relationship.

The developing focus within the relational movement to think about the interpersonal field and the role of "relationship" has led to a close engagement between the relational community and its ideas and fields such as attachment theory (the IARPP conference held in 2008 in Baltimore was focused on the relationship between attachment theory and relational ideas). The discussion of the "developmental tilt" in psychoanalysis, and subsequently in relation to relational psychoanalysis, was the subject of one of Mitchells (1984) papers, and more recently Dan Hill's Affect Regulation Theory: A clinical model (2015) demonstrated the way in which the drawing together of intellectual traditions in both areas, research across disciplines, and clinical work has shifted and changed as a result of the "paradigm shift" which accompanied the development of relational thinking.

Those collaborative approaches are evident in every conference, plenaries feature research in neuropsychology and neurobiology, early infant research (the work of Dan Stern), the value of creative engagement (both in terms of "body work" and the engagement of thinking about vitality and creativity in the life of both the therapist and the client and work which attempts to bridge cultural differences and divides.

Theorising in the field has viewed the relational "object" as fluid, changed by and changing the relational space so that the self is re-organised within the relational context. The elaboration of a narrative between participants creates both emotional availability and depth.

The 1oth Anniversary Stephen Mitchell Memorial Conference (New York, 2012) featured a plenary with Irwin Hoffman and Donnel Stern with the following description:

This panel will explore the dialectical interplay in the analyst's experience of finding himself or herself 'feeling inclined' to act and proactively exercising will to influence the process. Sometimes what seems to be in the foreground is the sense of 'unbidden' experience that is the impetus for new understanding and action (Stern's emphasis), sometimes what is in the foreground is a sense of determination to affect the patient and the analytic relationship in a particular way (Hoffman's emphasis). The wellspring for the analyst's experience can never be fully known and yet certain moments become inspirational for creative exploration of new possibilities.

IARPP always attempts to create (even in cyber space) a relational context. The use of online colloquium draw the relational community together. Sam Gerson's (2009) paper "When Third is Dead" created just such a space leading Jessica Benjamin to comment, at its conclusion "this has been a gripping, moving and deeply unsettling experience". Andrew Samuels wrote of the same colloquium:

I was moved and amazed by the way this group of analysts managed to process and distil its ordinary political differences of opinion into something higher (or deeper). At the end, I feel that the colloquium attained a kind of ontological politics (a phrase that Steve Mitchell once used). 
More recently the clinical work of Donnel Stern featured in "Relational Freedom and Therapeutic Action" moderated by Steven Knoblauch and Alejandro Avila Espada (2014) was focused on "Stern discusses what he means by freedom in the activity of the analyst and illustrates the relationships between constriction, relaxation and relational freedom. We hope to continue our comparative thinking concerning similarities and differences, opportunities and constraints emerging for the clinical utility of these concepts."

Galit Atlas' (2015) paper “Touch Me, Know Me: The Enigma of Erotic Longing” featured. This paper moderated by Alejandro Avila Espada and Steven Knoblauch was described as an examination of the psychological experience of sexual longing. (Dr Atlas) She offers a way to think about erotic experience as a state of consciousness that connects us with material registered in the body. The paper addresses erotic longing and its relation to loss, and emphasises two simultaneous levels of existence. It proposes that Enigmatic and Pragmatic co-created interactions with the $(\mathrm{m})$ other always coexist and play a dual part in the otherness of lustful states of mind.

Hopefully this has been a brief but tantalising invitation into the relational movement and its way of relating and thinking about the human condition. Those interested are encourage to view the IARPP Website (http://iarpp.net) (Membership is very inexpensive for us here in New Zealand), to come to Sydney in 2017 (http://www.iarppsydney2017.com), and to access both Psychoanalytic Dialogues and the Relational Perspectives Book series (Analytic Press and Routledge).

\section{Lacanian Psychoanalysis - Gustavo Restivo}

Jacques-Marie-Émile Lacan was born in Paris on 13 April 1901 to a Catholic family. He attended a Jesuit school and went on to study medicine and later psychiatry. In 1927, he commenced his clinical training and began to work at different psychiatric institutions. Lacan attributed his "entry into psychoanalysis" to the influence of the famous psychiatrist Gaetan Gatian de Clérambault, whom he regarded as his "only master in psychiatry” (Lacan, 1966, p. 65). His doctoral thesis was “The Case of Aimée, or Self-punitive Paranoia” (1932). In 1934, he became a member of La Societe Psychoanalytique de Paris (SPP), and commenced a didactic analysis with Rudolph Lowenstein, under the umbrella of the International Psychoanalytic Association (IPA), lasting until the beginning of World War II. Following the war, he became a renowned and controversial figure in the international psychoanalytic community. Lacan was banned in 1962 from the IPA for his unorthodox views on the practice of psychoanalysis. In 1963, he founded L'Ecole Freudienne de Paris (EFP), a school of psychoanalysis dedicated to the training of analysts and the practicing of psychoanalysis. In 1980 Lacan dissolved the EFP, and constituted the Ecole for "La Cause Freudienne," saying: "It is up to you to be Lacanians if you wish; I am Freudian." (Lacan, 1980. p. 8). Lacan died in Paris on 9 September 1981 .

\section{The (Four) Fundamental Concepts of (Lacanian) Psychoanalysis}

To introduce and create a desire for further knowledge in readers who may not be familiar with the Lacanian orientation, the fundamental concepts of (Lacanian) psychoanalysis are briefly presented. 
In Lacan's Seminar XI, “The Four Fundamental Concepts of Psychoanalysis” (Lacan, 1964) are listed as Unconscious, Repetition, Transference and Drive. Lacan's point of reference in choosing those four concepts is Freud's metapsychology $(1915,1917)$. The unconscious and the drive are explicitly dealt with in the 1915 Metapsychology Papers. However, as Freud says, we may consider any work metapsychological insofar as it will "firstly clarify and carry deeper the theoretical assumptions on which a psychoanalytic system could be founded and secondly, have the value of a founding concept" (1915/1957, p. 222). There are other primary Freudian concepts such as repression, resistance, sublimation, affect, anxiety, the ego, the id, the superego; and in Lacan's own formalisations, concepts like the Other, desire, jouissance, the name of the father, the real, the imaginary, the symbolic, that also may deserve to be called fundamental.

\section{The unconscious}

The unconscious maintained in accord with my inaugural resolution as an effect of the signifier and structured like a language was here taken up as a temporal pulsation. (Lacan, 1964, p. 154)

Lacan maintained that the unconscious is an effect of language, meaning that the Freudian unconscious is not a primary natural given which we have always known to have existed. Implicit in Freud is the primacy of the symbolic order and it is only in the interaction between the subject and that order that the unconscious is constituted. Much of Seminar XI is based on clarifying the concept of Vorstellungsrepresentanz, the representative of a representation in this context, but what Lacan emphasises is the notion of the unconscious as a temporal pulsation which appears to be more primary than its linguistic structure, the unconscious opens and closes, there is a temporal pulsation and it can be experienced anytime somebody speaks, particularly in an analytic session. For a moment something opens and then closes to produce a disturbance of the conscious organisation that governs the subject's speech and it is there that the analyst is called on to intervene by revealing to the subject, in his own speech, something about his position of which he knew nothing, as an unconscious knowledge.

\section{Repetition}

In repetition, the function of tuche was brought to light as it had been concealed behind the appearance of automaton: a missed encounter is highlighted in relation to the real as impossible. Repetition has been seen in analysis as analogous to the automatism of a habit; an unconscious template that the subject repeats without knowing that he/she is repeating it. In particular, repetition is supposed to govern transference reactions in the analytic situation and this was in fact the way that the concepts of repetition and transference were first introduced by Sigmund Freud. One of the main tasks Lacan set himself in Seminar XI (1964) was to disentangle those two concepts and to redefine each of them in a way that does not make repetition dependent on transference.

The primary point to be established is that repetition, which is the English translation for Wiederholung, means dragging something up again. Is not determined by habit, but by 
chance, luck, or fortune. What is repeated is not what is learned from experience and what the subject has more or less consciously mastered, but what has escaped him/her, what the subject has not grasped, the tuche of the missed encounter. It is commonplace in analysis to say that traumatic experiences are repeated, but trauma is precisely defined as what could not be mastered, assimilated or understood. Therefore, personal history revolves around that which has failed to achieve a representation (a Vorstellung).

\section{Transference}

Lacan highlighted the point that "temporal pulsation" is considered as a primary feature of the unconscious. The unconscious opens with repetition and closes with transference. Lacan described transference as something that begins once there is a subject who is supposed to know. In this sense there is transference when the initial assumption that the analyst knows about the subject's symptoms occurs.

Analysis proper begins when the subject enters into a transference with the analyst. If that does not occur and the subject does not assume that the analyst knows, the subject does not enter analysis, and if they do go, they do not stay. The crucial moment in the development of the transference is when the presumption of knowledge is transformed into a love, a deceptive love which results in the closure of the unconscious.

In Desire and its interpretation (Lacan, 1958), Lacan articulates the way in which Socrates was first approached by his disciples as the one who knew and then became an object of their love. This transference love was seen by Freud, from the beginning, as the main agent of change in analysis. This love is deceptive because like all love it is essentially narcissistic. It is the assumption that the other has what I am lacking, and that the other as my beloved can make up for what I am lacking. In persuading the other that they have what can complement us, we assure ourselves of being able to continue to misunderstand precisely that which we lack.

Lacan modified both notions of repetition and transference and distinguished them from one another. He stated that the notion of transference was simply a repetition of a previous situation is a way for the analyst to disavow his/her place in the transference, thereby laying the entire responsibility for transference reactions onto the shoulders of the analysand. On the contrary, Lacan emphasised that the desire of the analyst has a greater influence on the way the transference develops than the predispositions that the patient brings to the analysis. This places the accent on the synchronic rather than the diachronic, while at the same time radically rejecting the contemporary obsession with the analyst's counter-transference reactions.

\section{Drive}

Perhaps the most useful thing that can be said about the drive is to refer the reader to Lacan's extensive commentary on Instincts and their Vicissitudes (Freud, 1915) a text which made some useful remarks about the four interlocking components of the drive - source, pressure, aim, and object. Lacan treated it as one of Freud's most intelligent accounts of the nature of human love and the way in which it is related to the partial drives of sadism, voyeurism, and narcissism.

The point that Lacan highlighted regarding the constancy of the drive comes straight 
from Freud and is what led him to argue that drives have no day or night, no summer or winter - that they do not abate when they are satisfied, but instead exercise this konstante Kraft, a constant force. Lacan explained why it is precisely the oral, anal, visual, and auditory orifices that are privileged by Freud as sources of the drive. The return action refers to the reversal of aim or object that Freud saw as one of the vicissitudes to which drives may be subjected - to look or be looked at, to hurt or to be hurt, and so on.

For Lacan, René Descartes anticipated Freud in his search, not for knowledge, but for certainty. Descartes subverted all knowledge by his methodical doubt and was left with only the certainty of a subject of thinking from whom all other qualities had been stripped. Psychoanalysis gives this subject the quality of being a desirer transforming the Cartesian Cogito into a Freudian Desidero. Freud was a true successor to Descartes when he wrote: "I have never been concerned with any comprehensive synthesis but with certainty alone" (Freud, Andreas-Salomé, \& Pfeiffer,1972, p.32). Lacan stated that it is certainty, rather than hypotheses, that should guide the interventions of the psychoanalyst. The analyst is not the possessor of a general knowledge which is then applied to particular cases, as Lacan quoted Pablo Picasso: "I do not search, I find" ( as cited in Van Velde,1966, p. 59). The analyst is not to construct theories about the subject who is speaking to him; the analyst is there to hear and to reveal to that subject the incontrovertible signifiers which appear concretely in his spoken discourse.

The subject of the drive in Seminar XI appears to be assimilated to the subject of certainty. The drive that Lacan takes as a paradigm for the operation of all the others, the scopic drive, does indeed show that the apparently primordial cogito. The way in which we normally organise our visual world involves the masking of this dimension of being seen, the gaze - which is thus promoted to the status of lost object, excluded from our world of representations but a key element in our unconscious phantasies. When this object does intrude into the world of representations it is perceived as uncanny and is Lacan's way of presenting the object of anxiety or the object cause of desire - one manifestation of what he describes as the object $a$.

\section{Lacanian Psychoanalysis in Aotearoa New Zealand}

Gustavo Restivo, a Lacanian trained psychoanalyst from Buenos Aires, arrived in Auckland in 1999. At that time the development of the Freudian field of psychoanalysis with the Lacanian orientation was non-existent. In 2004, academic staff from Auckland University, set up the first Aotearoa New Zealand seminar for psy-professionals, academic staff, and graduate students interested on the work of Lacan by inviting Dr Dany Nobus, a Belgium psychoanalyst, working at that time at Brunel University, London. In collaboration with Dr. Leonardo Rodriguez, of the Center for Lacanian Analysis (CLA), and other Lacanian analysts and interested academics, the CLA was established in Aotearoa New Zealand in 2006. The first director was Gustavo Restivo. The CLA aimed to set up a training for analysts within the Lacanian orientation and to support the extension of psychoanalysis by facilitating collaborative work between psychoanalysis and other disciplines. The Centre has organised numerous international conferences, clinical seminars, and study groups in Aotearoa New Zealand.

The CLA had the honor of hosting Dr. Sonia Alberti, a distinguished Brazilian psychoanalyst, in 2008 and 2009. Members of the CLA engaged in discussion with Sonia 
Alberti regarding CLA involvement with an international school of psychoanalysis. Dr. Alberti introduced the activities of the Ecole de Psychanalyse des Forums du Champ Lacanien and encouraged the CLA to explore their desire to be part of a School of Psychoanalysis. The International Forum unites the activities of the Forums of the Lacanian field. The Forums arose out of the dissolution of the School of Lacan, the EFP (École Freudienne de Paris), in 1980.

The CLA decided to work in collaboration with the School of Psychoanalysis and created the New Zealand Forum. In March 2009, members of the CLA presented a request to create the Forum of New Zealand and to be part of the English-speaking group. The proposal was approved in principle, and subsequently Dr. Restivo went to represent the group at the Sixth Meeting of the Forums in Rome in July 2010, where it was formally ratified. Currently the CLA and the New Zealand Forum are committed to promoting Lacanian psychoanalysis in Aotearoa New Zealand.

In 2016, the Centre for Lacanian Analysis created a clinical placement available to students who are enrolled in clinical papers in the Master of Psychotherapy programme at the Auckland University of Technology who have the desire to work as clinicians in the Lacanian field.

\section{Concluding thoughts}

This paper discussed three styles of psychodynamic psychotherapy commonly practiced in Aotearoa New Zealand. As the reader, you will have noticed the difference in writing styles of the three expert authors. My (Mark's) view is that they echo the style of the object relations, relational psychoanalysis, and Lacanian orientations to psychoanalytic psychotherapy. This may be seen as a reflection of the diversity of psychoanalytic thought and practice, which suits different clients and therapists.

In conclusion, Shedler's $(2006,2010,2015)$ papers, based on a review of recent psychotherapy process literature (Blagus \& Hilsenroth, 2000, 2002), are worth mentioning. Shedler states that the distinctive features of psychodynamic psychotherapy were found to be; a focus on affect and the expression of emotion, exploration of attempts to avoid distressing thoughts and feelings (defences), identification of recurring themes and patterns, discussion of past experiences (developmental focus), emphasis on interpersonal relationships, focus on the therapy relationship (specifically the transference and countertransference dimension), and the exploration of phantasy life. It is an interesting question, left to the reader as before to what extent these features are reflected in the object relations, relational psychoanalytic, and Lacan orientations as discussed in this paper.

\section{References}

Atlas, G. (2015). Touch me, know me: The enigma of erotic longing. Psychoanalytic Psychology, 32 (1), 123-139. doi: $10.1037 / \mathrm{a} 0037182$

Atlas-Koch, G., \& Kuchuck, S. (2012). To have and to hold: Psychoanalytic dialogues on the desire to own. Psychoanalytic Dialogues, 22, 93-105. 
Benjamin, J. (1988). The bonds of love: Psychoanalysis, feminism, and the problem of domination. New York , NY: Pantheon.

Benjamin, J. (1995). Like subjects, love objects. New Haven, CT: Yale University

Blagus, M. D., \& Hilsenroth, M. J. (2000). Distinctive activities of short-term psychodynamicinterpersonal psychotherapy: A review of the comparative psychotherapy process literature. Clinical Psychology, 8, 167-188. doi:10.1093/clipsy.7.2.167

Blagus, M. D., \& Hilsenroth, M. J. (2002). Distinctive activities of cognitive-behavioral therapy: A review of the comparative psychotherapy process literature. Clinical Psychology Review, 22(5), 671-706. doi:10.1016/So272-7358(01)00117-9

Blumenfeld Hoadley, J. (2016). Miss V's universe - from awe to eew! and back again. Australasian Journal of Psychotherapy, 34(2), 59-80.

Britton, R. (2004). Subjectivity, objectivity, and triangular space. The Psychoanalytic Quarterly, LXXIII(1), 47-61. doi:10.1002/j.2167-4086.2004.tboo152.x

Dumont, F. (2008). Introduction to 21st-Century psychotherapies. In R. Cornisi, J. \& D. Wedding (Eds.), Current psychotherapies (9th Ed.; pp.1-13). Toronto, Canada: Brooks Cole.

Fairbairn, W. R. D. D. (1941). A revised psychopathology of the psychoses and psychoneuroses. International Journal of Psychoanalysis, 22, 250-271.

Fairbairn, W. R. D. D. (1943). The repression and the return of bad objects. British Journal of Medical Psychology, 19.

Fairbairn, W. R. D. D. (1944). Endopsychic structure considered in terms of object-relationships. International Journal of Psychoanalysis, 25, 70.

Fairbairn, W. R. D. D. (1949). Steps in the development of an object-relations theory of the personality. British Journal of Medical Psychology, 22(1-2), 26-31.

Fairbairn, W. R. D. (1952). Psychoanalytic studies of the personality. London, United Kingdom: Routledge and Kegan Paul.

Feltham, C. (1997). Which psychotherapy? Leading exponents explain their difference. London, United Kingdom: Sage.

Fonagy, P. (2001). Attachment theory and psychoanalysis. London, United Kingdom: Karnac.

Framo, J. L. (1976). Family of origin as a therapeutic resource for adults in marital and family therapy: You can and should go home again. Family Process, 15(2), 193-210. doi:10.1111/j.1545-5300.1976.00193.x

Freud, S.E. (1957). Instincts and their Vicissitudes. In Stratchey, J. (Ed. and Trans.), The Standard Edition of the Complete Psychological Works of Sigmund Freud, Vol. XIV (1914-1916): On the History of the Psycho-Analytic Movement, Papers on Metapsychology and Other Works (pp. 109-140). London, United Kingdom: Vintage. (Original work published 1915).

Freud, S. E. (1917). A metapsychological supplement to the theory of dreams. London, United Kingdom: Vintage.

Freud, S.E. (1957). Mourning and Melancholia. In Stratchey J. (Ed. and Trans.) The Standard Edition of the Complete Psychological Works of Sigmund Freud, (Vol. XIV, 1914-1916): On the History of the Psycho-Analytic Movement, Papers on Metapsychology and Other Works (pp. 237-258). London, United Kingdom: Vintage. (Original work published 1917).

Freud, S. E. (1923). Certain neutoric mechanisms in jealousy, paranoia and homosexuality. The International Journal of Psychoanalysis, 4, 1-10.

Freud, S.E., Andreas-Salomé, L., \& Pfeiffer, E. (1972). Sigmund Freud and Lou Andreas-Salomé--letters: 
Chatto \& Windus.

Gerson, S. (2009). When the third is dead: Memory, mourning, and witnessing in the aftermath of the holocaust. The International Journal of Psychoanalysis, 90, 1341-1357.

doi:0.1111/j.1745-8315.2009.00214.x

Ghent, E. (2002). Relations: Introduction to the First IARPP Conference. IARPP eNews: A Quarterly Electornic Peridiocal of the International Association for Relational Psychotherapy and Psychoanalysis, 1(1), 7-9.

Hayman, A. (1994). Some remarks about the 'controversial discussions'. International Journal of Psychoanalysis, 75 ( Pt 2), 343-358.

Hill, D. (2015). Affect regulation theory: A clinical model. New York, NY: W.W. Norton.

Hinshelwood, R. D. (1988). A dictionary of Kleinian thought. London, United Kingdom: Free Association Books.

Issacs, S. (1948). The nature and function of phantasy. International Journal of Psychoanalysis, 29, 73-97.

Klein, M. (1946). Notes on some schizoid mechanisms. International Journal of Psychoanalysis, 27, 99-110.

Lacan, J. (1932). Le cas Aime ou la paranoia d'auto-punition, De la Psychose Paranoiaque dans ses Rapports avec la Personalitd. Retrieved from http://www.mediafire.com/file/x88w1gd66caazwo /19320101+Lacan+Aimee.PDF

Lacan, J. (1958). The Seminar of Jacques Lacan: Book VI: Desire and its Interpretation. Translation by Cormac Gallagher from unedited French typescripts. Retrieved from http://www. lacaninireland.com/web/wp-content/uploads/2010/o6/THE-SEMINAR-OF-JACQUESLACAN-VI.pdf .

Lacan, J. (1977). The Seminar, book XI, The Four Fundamental Concepts of Psychoanalysis (1964). Trans. Alan Sheridan. London, United Kingdom: Hogarth Press and Institute of Psychoanalysis, 41.

Lacan, J. (1980). The Seminar of Jacques Lacan Book XXVII, Caracas. Melbourne, Australia: PIT Press, 1981.

Lebow, J. J. (2017). Twenty-First century psychotherapies: Contemporary approaches to theory and practice. London, United Kingdom: John Wiley \& Sons.

Mitchell, S. A. (1984). Object relations theories and the developmental tilt. Contemporary Psychoanalysis, 20, 473-499.

Ogden, T. H. (2002). A new reading of the origins of object-relations theory. The International Journal of Psychoanalysis, $83,767-782$.

Racker, H. (1953). A contribution to the problem of counter-transference. International Journal of Psychoanlaysis, 34, 313-324.

Racker, H. (1957). The meanings and used of countertransference. Psychoanalytic Quarterly, 26, 303-357.

Sandler, J. (1976). Countertransference and role-responsiveness. International Review of Psychoanalysis, 3, 43-48.

Scharff, M., \& Scharff, J. S. (1977). Object relations family therapy. New York, NY: Jason Aronson, Incorporated.

Scharff, M., \& Scharff, J. S. (2000). Object relations couple therapy. New York, NY: Jason Aronson, Incorporated. 
Shedler, J. (2006). That was then, this is now: An introduction to contemporary psychodynamic therapy. Unpublished paper: University of Colorado School of Medicine. Retrieved from http://www.jonathanshedler.com/PDFs/Shedler\%20\%282006\%29\%20That\%20was\%20 then,\%2othis\%2ois\%2onow\%2oR9.pdf

Shedler, J. (2010). The efficacy of psychodynamic psychotherapy. American Psychologist, 65(2), 98109.

Shedler, J. (2015). The therapy relationship in psychodynamic therapy versus CBT. Psychology Today.

Skynner, A. C. (1976). Systems of family and marital psychotherapy. Oxford, United Kingdom: Brunner/Mazel.

Thorpe, M. R. (2015). Psychoanalytic sensibility in a behavioural world: Supervising intern counselling psychologists in Aotearoa New Zealand. In Z. G. Knight (Ed.), Psychoanalysis: Perspectives, techniques and socio-psychological implications (pp. 31-50). New York, NY: Nova Science Publishers.

Van Velde, B. (1966). Conversations with Samuel Beckett and Bram van Velde. London, United Kingdom.

Winnicott, D. W. (1953). Transitional objects and transitional phenomena. International Journal of Psychoanalysis, 34, 89-97.

Winnicott, D. W. (1969). The use of an object. International Journal of Psychoanalysis, 50, 711-716.

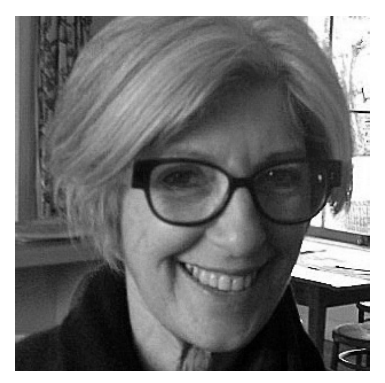

Judi Blumenfeld Hoadley is a psychoanalytic psychotherapist and clinical supervisor in private practice. She sees adults, couples, and adolescents and offers supervision to a broad range of health professionals. She has for many years been actively involved in teaching and training psychotherapy theory and practice in a number of settings, including the New Zealand Institute of Psychoanalytic Psychotherapy, Auckland University of Technology, NZAP, and the Auckland Psychiatry Registrar Programme. She is a founding member and former Training Convenor of NZIPP and a former Training Chair of the PPAA. She has presented and published papers on a range of psychoanalytic topics. Contact details: judi.jbh@gmail. com .

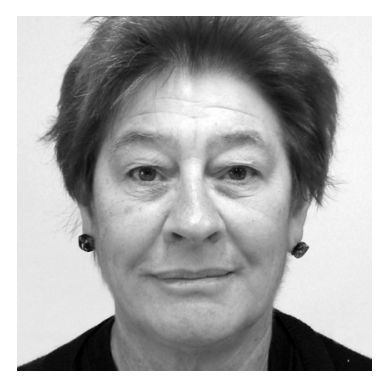

Dr Sarah Calvert is a clinical psychologist and psychotherapist whose working life has been focused on working primarily with women and children in areas such as attachment and trauma. Sarah gained her PhD from Waikato University and has worked in private practice (where she sees clients for psychotherapy and does supervision) and assessments for the Family and Criminal Courts and ACC. Her interest in relational psychoanalysis and psychotherapy was a natural progression 
of her seeking to learn more about attachment and the role of the therapist in all forms of therapy. She "discovered" the work of Stephen Mitchell, the founder of IARPP (International Association of Relational Psychoanalysis and Psychotherapy), and was an early attender at web-based seminars run by Stephen and Lew Aron in 1999. She joined IARPP at its inception and has attended most conferences. Sarah is current a co-chair (with Cathy Hicks of Australia) of the 2017 IARPP International Conference to be held in Sydney in May of this year. Readers are urged to look at the conference web site for a taste of the conference http:// www.iarppsydney2017.com. Contact details: calverts@iconz.co.nz .

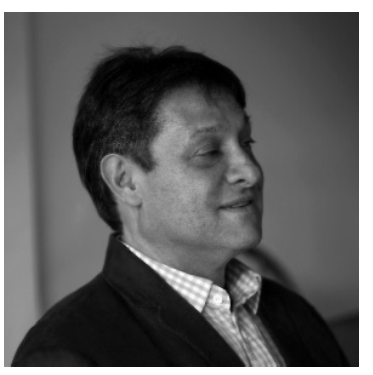

Dr Gustavo Restivo trained as a clinical psychologist and psychoanalyst in the Freudian field and the Lacanian orientation at the Argentinean University J. F. Kennedy, Buenos Aires, where he lectured in the Department of Psychoanalysis. He immigrated to Aotearoa New Zealand in 1999. Dr Restivo is a founding member and current director of the Centre for Lacanian Analysis and of the New Zealand Forum, which belongs to the International School of Psychoanalysis of the Forums of the Lacanian Field. He is the current Chairperson of the New Zealand Institute of Psychoanalytic Psychotherapy. He completed a PhD at Auckland University of Technology in 2013, his PhD thesis was "Jouissance and the Sexual Reality of the (Two) Unconscious". Dr Restivo is author of numerous articles on psychoanalytic theory and practice and has presented papers in Aotearoa New Zealand and internationally. Contact details: bartoli.restivo.psyconsulting@gmail.com .

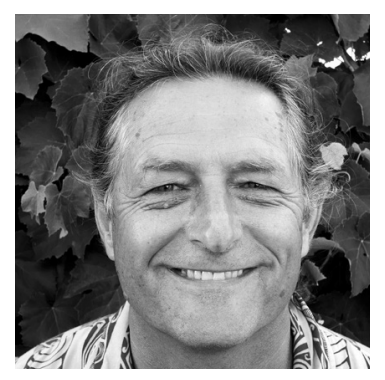

Dr Mark Thorpe is a senior lecturer at Auckland University of Technology and practices as a clinical psychologist at Psychotherapy at Apollo. He trained in a variety of therapeutic modalities and worked in private, governmental, and university settings in South Africa and Aotearoa New Zealand. Mark is Chair of Training for the New Zealand Institute of Psychoanalytic Psychotherapy, and a member of the Psychoanalytic Psychotherapy Association of Australasia and the International Association of Relational Psychotherapy and Psychoanalysis. He has held the positions of Vice President of the South African Institute of Psychotherapy, Chairperson of the Cape Town Psychoanalytic Society, Psychology Professional Advisor for Pacific Health DHB, Committee Member of the NZ Institute of Counselling Psychology, and Head of Psychology at Auckland University of Technology. Contact details: mark.thorpe@aut.ac.nz . 